\title{
CÂTEVA CONSIDERAȚII PRIVIND LEGĂTURA DINTRE ASIGURAREA SUSTENABILITĂȚII MEDIULUI ANTROPIC ȘI PROBLEMA CONSUMURILOR ENERGETICE ÎN ROMÂNIA
}

\author{
SOME CONSIDERATIONS ON THE RELATIONSHIP \\ BETWEEN PROVIDING SUSTAINABILITY IN THE \\ ANTHROPIC ENVIRONMENT AND THE ENERGY \\ CONSUMPTION PROBLEM IN ROMANIA
}

prof. dr. arh./prof. PhD arch. Ana-Maria Dabija

Universitatea de Arhitectură și Urbanism "Ion Mincu"/ Centrul de Studii Arhitecturale și Urbane "Ion Mincu"University of Architecture and Urbanism / Center for Architectural and Urban Studies am.dabija@uauim.ro 



\title{
Rezumat
}

Una din cele mai simple definiții ale sustenabilităţii este dată de Business Dictionary: ” abilitatea de a menține sau susține o activitate sau un proces pe termen lung”. Dicționarul Explicativ al Limbii Române dă o definiție a sustenabilității preluând ideea de bază a Raportului Brundtland din 1987, respectiv "calitate a unei activități antropice de a se desfășura fără a epuiza resursele disponibile și fără a distruge mediul, deci fără a compromite posibilitățile de satisfacere a nevoilor generațiilor următoare" și "care implică stabilirea unui echilibru între creșterea economică și protecția mediului şi găsirea de resurse alternative."

Lucrarea formulează câteva considerații referitoare la evoluția conceptului de sustenabilitate în relație cu modul în care se aplică măsurile de conservare a resurselor energetice tradiționale și extindere a utilizării surselor de energie "curată".

Cuvinte cheie: sustenabilitatea mediului antropic, energie, clădiri, arhitectură

\begin{abstract}
One of the simplest definitions of sustainability is given by the Business Dictionary: "The ability to maintain or sustain an activity or a long-term process." The Explanatory Dictionary of Romanian Language defines sustainability considering the basic idea of the 1987 Brundtland Report, respectively "the quality of an anthropic activity to run without exhaustion of available resources and without destroying the environment, thus without compromising the possibilities of satisfying the needs of the next generation "and" involving a balance between economic growth and environmental protection and finding alternative resources."

The paper presents some considerations regarding the evolution of the concept of sustainability in relation to the way the measures of preserving the traditional energy resources are applied while extending the use of "clean" energy.
\end{abstract}

Key words: sustainability of the anthropic environment, energy, buildings, architecture 


\section{Introducere}

Cercetări europene (Rees et al 1996 în Grierson, D. 2009) susțin de un timp că omenirea a atins și depăşit capacitatea de adaptare a planetei la consumurile crescânde și că deja deteriorarea ireparabilă a biosferei a început. Acest scenariu sumbru este confirmat de Global Footprint Network, care consideră că omenirea are deja nevoie de un an și șase luni pentru a regenera resursele pe care le utilizează într-un an. Sau de un Pământ și jumătate. Echilibrul pare a se fi pierdut cândva la începutul anilor șaptezeci ai secolului trecut.

Aceeași organizație afirmă că "pretențiile pe care le formulează omenirea asupra ecosistemelor Pământului vor depăși capacitatea de regenerare a naturii cu aproximativ $75 \%$ până în 2020. Trebuie să începem să stabilim limitele ecologice esențiale pentru luarea deciziilor noastre și să folosim ingeniozitatea umană pentru a găsi noi moduri de a trăi bine, în limitele Pământului.".

Pericolul epuizării resurselor naturale a fost semnalat încă din secolele al XVII-lea și al XVIII-lea, în relație cu defrișarea pădurilor din Europa. În eseul Sylva publicat în 1662, britanicul John Evelyn afirma că "Plantarea copacilor trebuie considerată o datorie națională a fiecărui proprietar de teren, pentru a opri supra-exploatarea distructivă a resurselor naturale"2

Preocupările pentru studiul interdependenței dintre creșterea producției alimentare a unei națiuni, creșterea populației și bunăstarea acesteia au fost studiate de Thomas Robert Malthus în numeroase lucrări dintre care cel mai adesea este menționat eseul Principiul Populației publicat în 1798. Deși identifică problema epuizării resurselor, soluția promovată de el, de decimare a populației, pare, am spune... nesustenabilă: " Forța populației este în asemenea măsură superioară capacității pământului de a asigura subzistenţa oamenilor încât, într-un fel sau altul, rasa umană trebuie vizitată, într-o formă sau alt, de moarte prematură. "”3 (Malthus T.R. 1798) .

La mijlocul secolului al XX-lea, îngrășămintele sintetice, erbicidele și pesticidele îi determină - din nou - pe oamenii de știință să tragă semnalul de alarmă cu privire la consecințele devastatoare ale acțiunii oamenilor pentru viața planetei.

Agenția Statelor Unite pentru Protecția Mediului consideră că unul dintre primele documente scrise privind durabilitatea este Legea privind Politica Naţională de Mediu din 1969 (NEPA), care stabilește un cadru național pentru protecția mediului.

\section{Dezvoltare sustenabilă. Elemente de bază.}

Raportul "Viitorul nostru comun" - cunoscut și ca Raportul Brundtland, cel care deschide seria, în 1987, conferințelor, rapoartelor și în general preocupărilor coordonate la nivel mondial de asigurare a unui mediu de viață durabil - este urmat în 1992 de "Earth Summit", Conferința Naţiunilor Unite de la Rio de Janeiro din care derivă numeroase alte summitt-uri Rio $(+5)$, Rio(+10), Rio(+20), la 5, 10 și 20 de ani respectiv, fiecare cu programe de măsuri.

\footnotetext{
1 trad. ns.

2 trad. ns.

${ }^{3}$ trad. ns.
} 


\section{Introduction}

European research (Rees et al. 1996 in Grierson, D. 2009) has for some time been claiming that mankind has reached and exceeded the adaptability of the planet to increasing consumption, and that irreparable damage to the biosphere has already begun. This grim scenario is confirmed by the Global Footprint Network, which believes that mankind already needs a year and six months to regenerate the resources it uses in a year. Or one and a half Earth. Balance seems to have been lost sometime in the early seventies of the last century.

The same organization claims that "Human demand on the Earth's ecosystems is projected to exceed what nature can regenerate by about 75 percent by 2020 . We must begin to make ecological limits central to our decision-making and use human ingenuity to find new ways to live well, within the Earth's bounds."

The danger of exhaustion of natural resources has been signaled since the 17th and 18th centuries in relation to the deforestation of forests in Europe. In the Sylva essay published in 1662, the British John Evelyn stated that "planting of trees had to be regarded as a national duty of every landowner, in order to stop the destructive over-exploitation of natural resources".

Concerns about the study of the interdependence between the growth of a nation's food production, population growth and well-being have been studied by Thomas Robert Malthus in numerous papers, most frequently mentioned in the Population Principle published in 1798. While identifying the problem of resource depletion, the solution that he identifies - decimation of the population - seems, we would say ... totally unsustainable: "The power of population is so superior to the power of the earth to produce subsistence for man, that premature death must in some shape or other visit the human race. " (Malthus T.R. 1798)

In the middle of the twentieth century, synthetic fertilizers, herbicides and pesticides again led scientists to signal the devastating consequences of human action for the life of the planet.

The United States Environmental Protection Agency considers one of the first written documents on sustainability to be the 1969 National Environmental Policy Act (NEPA), which establishes a national framework for environmental protection.

\section{Sustainable development. Basics.}

The report "Our Common Future" - also known as the Brundtland Report, the one that opens, in 1987, the series of conferences, reports and generally global coordinated concerns to ensure a sustainable living environment - was followed in 1992 by the "Earth Summit", The United Nations Rio de Janeiro Conference, which brings many other summits Rio $(+5)$, Rio $(+10)$, Rio $(+20)$ to 5, 10 and 20 years respectively, each with programs of measures . 
Încă de la conferința de la Rio s-au pus bazele construcției conceptului dezvoltării durabile, respectiv dezvoltarea echilibrată a trei piloni care ulterior au devenit patru sau cinci.

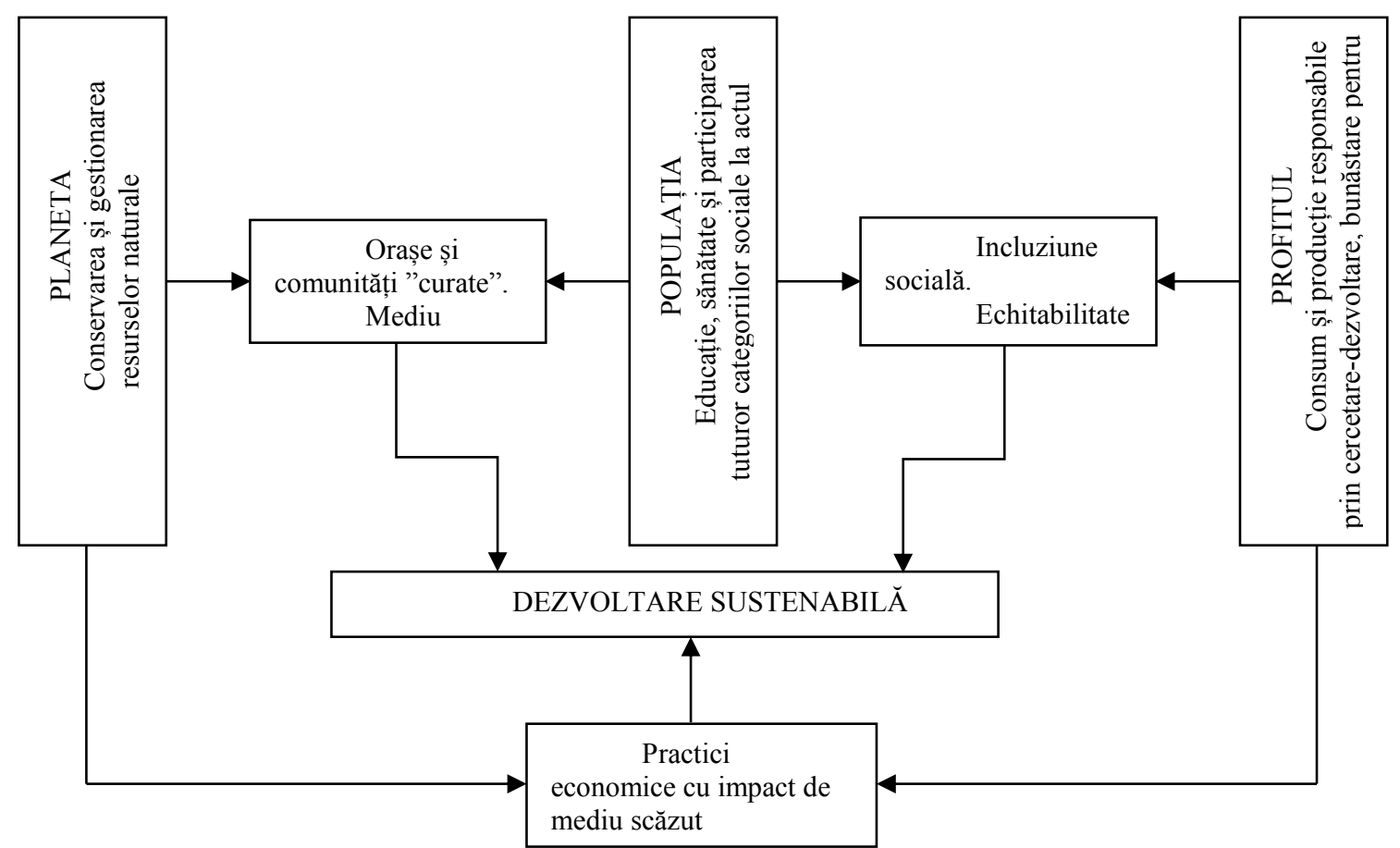

Fig. 1 Schema pilonilor de bază ai dezvoltării sustenabile / durabile a planetei

Pilonii de bază (Fig. 1) sunt:

- Planeta (mediul natural care include atmosfera, apele, pădurile, biosfera în general)

- Populația (asigurarea sănătății, educației și implicarea în viața socială a tuturor categoriilor umane și socio-profesionale)

- Profitul (asigurarea locurilor de muncă, dezvoltarea tehnologică, creșterea economiei).

Derivați din pilonul social (al populației) pilonul cultural și cel al siguranței răspund unor necesități contemporane (multiculturalism și lupta împotriva terorismului de pildă).

Dezvoltarea sustenabilă presupune ca fiecare dintre piloni să funcționeze în armonie cu ceilalți, la intersecția dintre ei fiind locul geometric al sustenabiliății. $\mathrm{Cu}$ alte cuvinte dezvoltarea sustenabilă reprezintă suma căilor și mijloacelor prin care se atinge obiectivul pe termen lung, acela de a asigura funcționarea sistemului Pământ fără a-l distruge.

\section{Performanța energetică a clădirilor și teoria dezvoltării durabile, aplicată în}

\section{România}

Consiliul Uniunii Europene trasează încă din anul 2004, prin raportul "Towards a thematic strategy on the urban environment" patru direcții de acțiune: trei referitoare la politici și acțiuni la nivel urban (management al mediului urban, transport urban, proiectare urbană) o direcție referitoare la construire sustenabilă. 
Since the Rio conference, the concept of sustainable development has been built, ie the balanced development of three pillars that have later become four or five.

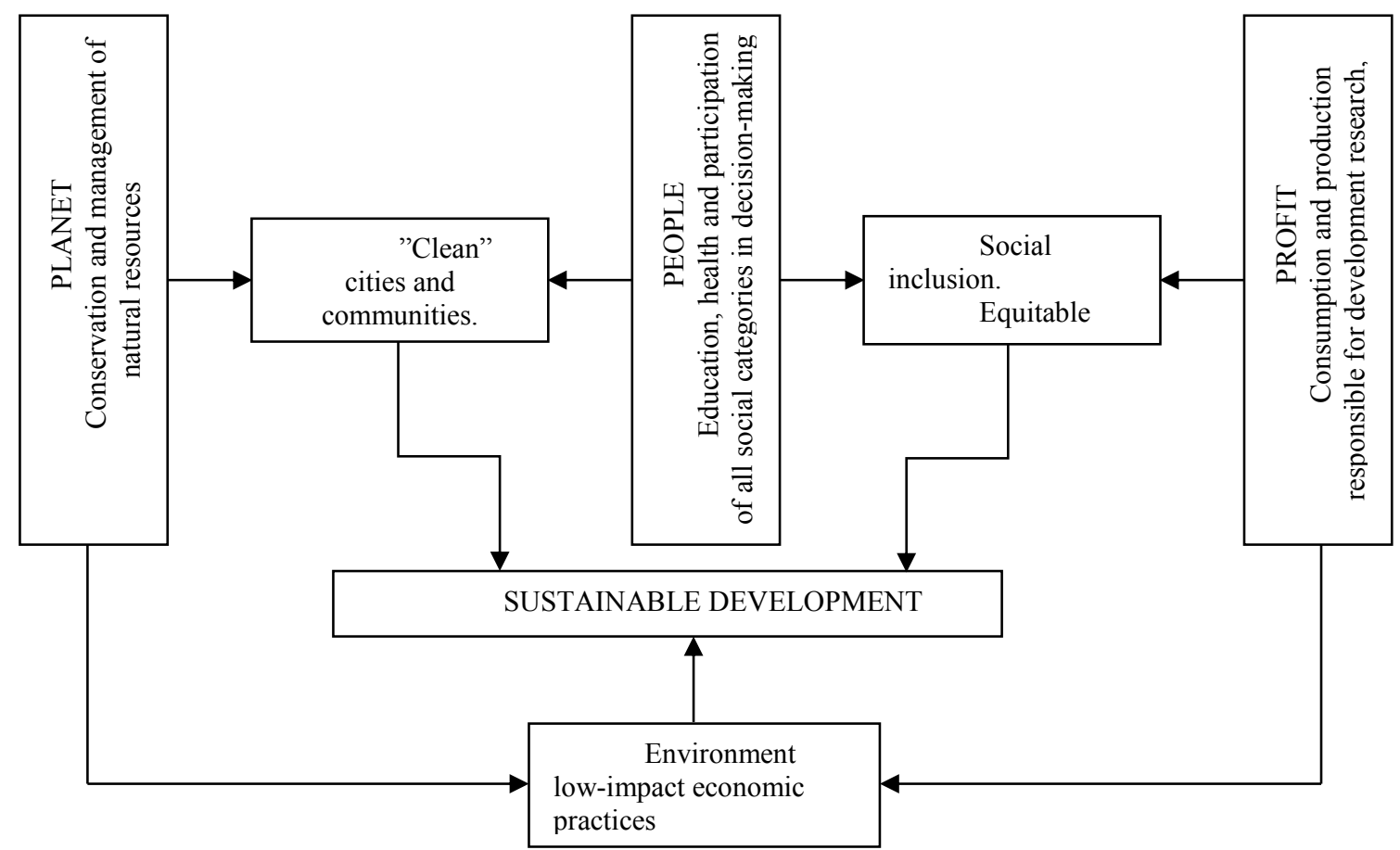

Fig. 1 Scheme of the basic pillars of the sustainable / sustainable development of the planet

The main pillars (Fig. 1) are:

- Planet (the natural environment that includes the atmosphere, waters, forests, the biosphere in general)

- People (health, education and social inclusion of all human and socio-professional categories)

- Profit (job creation, technological development, growth of the economy).

Derived from the social pillar (the People) the cultural and security pillars respond to contemporary needs (multiculturalism and the fight against terrorism, for example).

Sustainable development requires each of the pillars to work in harmony with others, at the intersection of which is the geometric place of sustainability. In other words, sustainable development is the sum of ways and means of achieving the long-term goal of ensuring the functioning of the Earth system without destroying it.

\section{Energy performance of buildings and the theory of sustainable development, applied in Romania}

Since 2004, the Council of the European Union has outlined four directions of action in the report Towards a thematic strategy on the urban environment: three on urban policy and actions (urban management, urban transport, urban design) to sustainable construction. 
În preambulul acestei direcții de acțiune se precizează că "Încălzirea și iluminatul clădirilor reprezintă cea mai mare parte din consumul de energie $(42 \%$, din care $70 \%$ reprezintă consumuri pentru încălzire) și produce $35 \%$ din toate emisiile de gaze cu efect de seră. Clădirile și mediul construit utilizează jumătate din materialele preluate de pe scoarța Pământului și sunt sursa a 450 de MT de deșeuri/an, rezultate din construcții și demolări (ceea ce reprezintă peste un sfert din totalul de deșeuri produse)" ${ }^{\text {"4 }} \mathrm{O}$ soluție pe care o propune raportul menționat este de reabilitare a fondului de clădiri existente prin termoizolarea lor, fapt care ar reduce emisiile de $\mathrm{CO}_{2}$ și costurile energetice cu $42-46 \%$. Deși se recunoaște că procesul de reabilitare / renovare este complex și complicat, intervențiile asupra fondului construit sunt oricum preferate demolării și reconstrucției dat fiind impactul deșeurilor (rezultate din construcții) asupra mediului. Totodată regenerarea urbană și reabilitarea clădirilor sunt considerate măsuri care, prin implicarea comunitătilor locale, ar putea să contribuie la aproprierea acestor zone / clădiri de către respectivele comunități.

Prima măsură unitară la nivel european pentru diminuarea consumurilor energetice în clădirile existente pare să fi fost adoptarea Directivei Europene privind performanța energetică a clădirilor.

În ceea ce privește România, această Directivă a condus la programul național de reabilitare termică a clădirilor de locuințe pe care nu-l putem defini ca fiind un succes, dimpotrivă! Unei idei generoase, de creștere a calității vieții în paralel cu diminuarea consumurilor energetice, i s-a contrapus o lipsă totală de viziune asupra arhitecturii clădirilor, atât la nivel holistic cât și la nivel de detaliu (care nu există). Completat cu o legislație șchioapă în ceea ce privește modul de achiziție publică a firmelor pentru construcții, programul național de reabilitare termică a distrus - putem spune - arhitectura fondului postbelic de locuințe (Dabija, A-M 2017, 2010). Sunt mult prea numeroase situațiile apartamentelor "reabilitate" care "beneficiază" de infiltrații de apă, mucegai, ciuperci, cauzele fiind relativ simple și mereu aceleași:

- proiectare sub minimele cerințe profesionale (lipsa detalierii personalizate, ținând cont de situația concretă a fiecărei clădiri / scări în parte)

- execuție la cel mai mic preț (cu personal necalificat și cu punerea în operă nu a unor sisteme de finisaj ci a unor elemente disparate a căror coerență constructivă nu este verificată)

Pe de altă parte adoptarea celor mai ieftine soluții de finisare va conduce inevitabil la nevoia ca în foarte puțini ani aceste fațade să aibă nevoie de reparații (Fig. 2).

Privind din perspectiva sustenabilității, praful, mizeria, gunoaiele, deșeurile ocazionate de aceste lucrări de intervenție sunt chiar cele pe care toate documentele mondiale le fac responsabile pentru poluarea planetei. Clădirile care au supraviețuit epocilor și stilurilor sunt realizate din - sau sunt finisate cu - materiale cu adevărat sustenabile care nu necesită cheltuieli de întreținere: piatră, cărămidă, lemn metal (Fig. 3) și-și păstrează neschimbat aspectul și expresia arhitecturală. E drept, au costat mai mult atunci când au fost realizate.

\footnotetext{
${ }^{4}$ Heating and lighting of buildings accounts for the largest single share of energy use $(42 \%$, of which $70 \%$ is for heating) and produces $35 \%$ of all greenhouse gas emissions. Buildings and the built environment use half of the material taken from the Earth's crust and are the source of 450 MT (n.t. $450 \times 10^{6}$ tons) construction and demolition waste per year (over a quarter of all waste produced). (Trad. Ana-Maria Dabija).
} 
The preamble to this line of action states that "Heating and lighting of buildings accounts for the largest single share of energy use ( $42 \%$, of which $70 \%$ is for heating) and produces $35 \%$ of all greenhouse gas emissions. Buildings and the built environment use half of the material taken from the Earth's crust and are the source of $450 \mathrm{MT}^{5}$ construction and demolition waste per year (over a quarter of all waste produced)". A solution proposed by the report is to rehabilitate the existing building stock by thermal insulation, which would reduce $\mathrm{CO} 2$ emissions and energy costs by $42-46 \%$. While recognizing that the rehabilitation / renovation process is complex and complicated, interventions on the built-up fund are anyway preferable to demolition and reconstruction due to the environmental impact of waste (resulting from construction). At the same time, urban regeneration and building rehabilitation are considered measures that, through the involvement of local communities, could contribute to the proximity of these areas / buildings by those communities.

The first unitary measure at European level to reduce energy consumption in existing buildings seems to have been the adoption of the European Energy Performance of Buildings Directive.

As far as Romania is concerned, this Directive has led to the national rehabilitation program for housing buildings that we can not define as a success, on the contrary! A generous idea of raising the quality of life along with the reduction in energy consumption was counterbalanced by a total lack of vision on the architecture of buildings, both at a holistic level and at a level of detail (which does not exist). Completed with legislation on the public procurement of construction companies, the national thermal rehabilitation program has destroyed - we can say - the architecture of the post-war housing fund (Dabija, A-M 2017, 2010). There are too many situations of "rehabilitated" apartments that "benefit" from water infiltrations, mold, mushrooms, the causes being relatively simple and always the same:

- design under minimum professional requirements (lack of personalized detail, taking into account the concrete situation of each building)

- - execution at the lowest price (with unqualified staff and putting into operation not finishing systems but disparate elements whose constructional consistency is not verified)

On the other hand, adopting the cheapest finishing solutions will inevitably lead to the need for these facades to need repairs in a few years (Fig. 2).

Looking from the perspective of sustainability, the dust, dirt, rubbish, debris, waste occurred by these interventions are the ones that all international documents point towards as being responsible for polluting the planet. Buildings that have survived epochs and styles are made of - or are being finished with - truly sustainable materials that do not require maintenance costs: stone, brick, metal (Figure 3) and retain their architectural appearance and expression unchanged. It is true, they cost more when they were made.

$5450 \times 10^{6}$ tons 

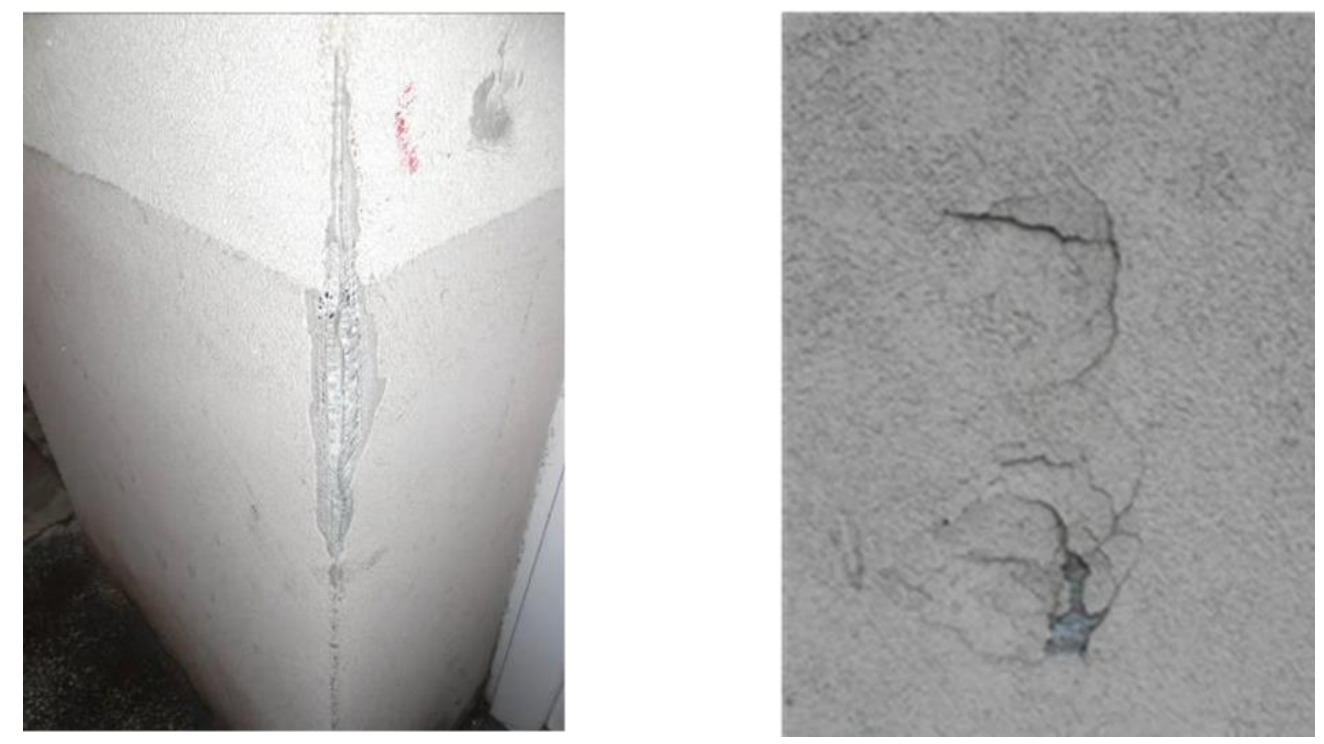

Fig. 2: Degradări ale finisajului fațadei înainte de plecarea constructorului de pe șantier Deterioration of the finish of the facade before the builder leaves the site

Un program interesant dar din păcate relativ nepromovat și necoordonat la nivelul ministerelor de resort este programul Casa Verde din cadrul Ministerului Mediului.

Beneficiind de resurse mult mai reduse decât cel de eficientizare energetică a locuințelor, programul Casa Verde promovează utilizarea energiilor neconvenționale în clădiri realizate din fonduri private.

Domeniile finanțate prin acest program sunt următoarele:

- instalarea de panouri solare

- instalarea de pompe de căldură

- producerea de energie bazată pe utilizarea deșeurilor (brichete, peleți, etc)

România fiind o țară cu risc seismic ridicat, între măsurile care susțin dezvoltarea durabilă ar trebui să se afle - nu doar declarativ ci prin măsuri reale - punerea în siguranţă structurală a patrimoniului construit. Prin programul național de consolidare a clădirilor cu risc seismic s-a reușit performanța de a consolida până în anul 2013 numai 8,4\% din cele 190 de clădiri cu "bulină", respectiv 16 clădiri.

Intervențiile de consolidare trebuie să fie urmate de modernizarea spațiilor, utilizând tehnologie contemporană, prilej cu care sistemele neconvenționale de producere a energiei sau de luminare artificială a spațiilor pot fi integrate. Un exemplu de abordare de la consolidare către conservare și producere a energiei din surse neconvenționale poate fi intervenția în podul clădirii istorice a Școlii de Arhitectură din București unde au fost prevăzute panouri fotovoltaice și tuneluri solare pentru producerea energiei necesare luminării spațiilor întunecoase (Fig. 4). 

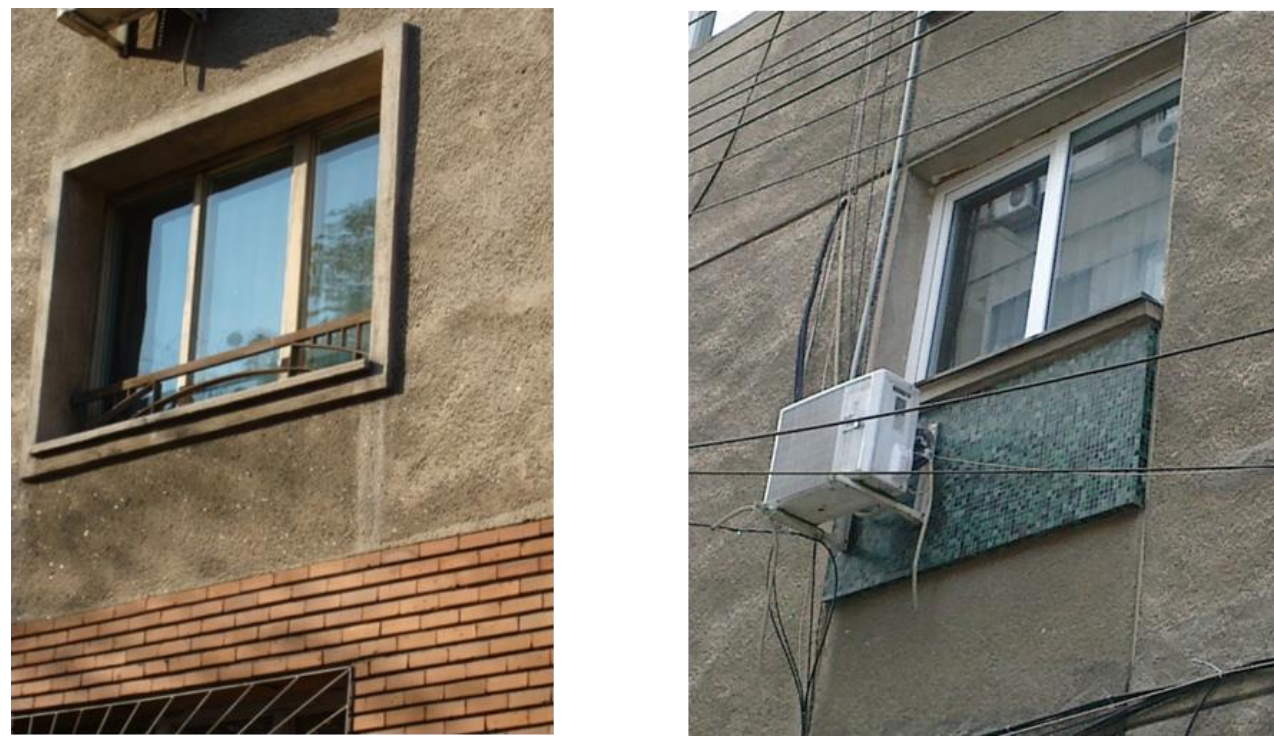

Fig. 3: Finisaje durabile la clădiri de locuințe din România care din păcate au fost distruse de furia reabilitărilor

Sustainable finishes at Romanian housing buildings, which were unfortunately destroyed by the fury of rehabilitation

An interesting program but unfortunately relatively unprompted and uncoordinated at the line ministries is the Green House program within the Ministry of Environment.

Featuring much lower resources than energy-efficient housing, the Green House program promotes the use of unconventional energies in private-funded buildings.

The areas funded under this program are as follows:

- installation of solar panels

- installing heat pumps

- $\quad$ energy production based on the use of waste (briquettes, pellets, etc.)

Since Romania is a country with a high seismic hazard, measures supporting sustainable development should be (not just declarative but real life - measures) structural safety of the built heritage. The national consolidation program for seismic risk in buildings has succeeded by 2013 to consolidate only 16 buildings s with "splat" which represents $8.4 \%$ of the total of 190 buildings with seismic hazard.

The consolidation interventions should be followed by the modernization of spaces, using contemporary technology, whereby unconventional systems of energy production or artificial lighting of spaces can be integrated. An example of an approach from consolidation to conservation and energy production from unconventional sources can be the intervention at the historic building of the School of Architecture in Bucharest, where photovoltaic panels and solar tunnels were provided to produce the energy needed to illuminate the dark spaces (Fig. 4). 


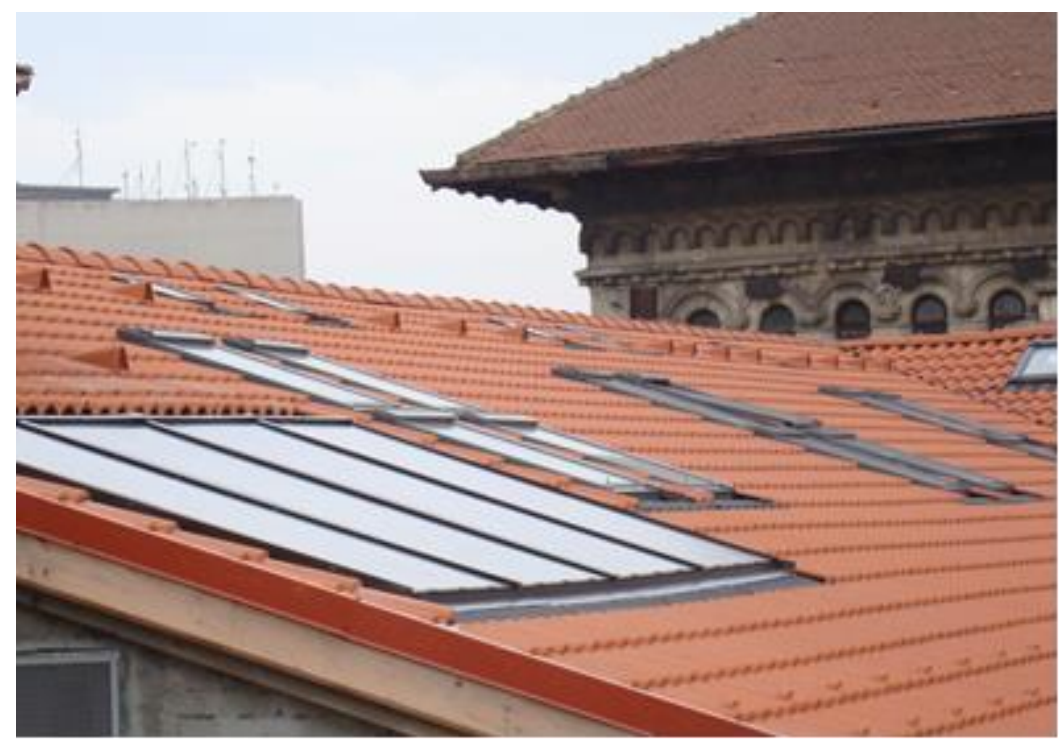

Fig. 4: "Coridorul solar” (Dabija, A-M 2016) al Universității de Arhitectură , panourile fotovoltaice și tunelurile solare

The "Solar Corridor" (Dabija, A-M 2016) of the University of Architecture, the photovoltaic panels and the solar tunnels

\section{Concluzii}

Considerăm că în ceea ce privește România, cheia sustenabilităţii nu este în primul rând eficiența energetică ci punerea în siguranță structurală a fondului de clădiri existente, prilej cu care se impune adoptarea de sisteme alternative de producere a energiei, nu de "păturici" termice, combinarea diferitelor sisteme care conduc la diminuarea consumurilor energetice după ce în prealabil clădirile au fost puse în siguranță din punct de vedere seismic. În mod evident acest demers presupune o proiectare mult mai atentă și o coordonare între specialiști din diferite domenii.

La fel de evident este că și costurile de investiție vor fi mai mari. În schimb, demersul va fi mai... durabil.

\section{Conclusions}

We believe that in Romania, the key to sustainability is not primarily the energy efficiency but the structural safety of the existing building stock, which is why it is necessary to adopt alternative energy production systems, not heat, the combination of the various systems that lead to the reduction of energy consumption after the buildings have been safely secured beforehand. Clearly this requires a much more careful design and coordination between specialists in different fields.

It is equally obvious that the investment costs will be higher. Instead, it will be more ... durable. 


\section{Referinţe/References}

Grierson, D. (2009) Towards a Sustainable Built Environment, în CIC Start Online Innovation Review, No. 1, 12.2009 , p. 70 - 78.

Malthus T.R. (1798). An Essay on the Principle of Population. Chapter VII, p 44.

*** Communication from the Commission to the Council, The European Parliament, The European Economic and Social Committee and the Committee of the Regions Towards a thematic strategy on the urban environment, Brussels, 11.02.2004, p. 20-24

Dabija, A-M (2017) Hell is Paved With Good Intentions! A Decade of Thermal Rehabilitations of Mass Buildings in Romania, în Interdiciplinary Perspectives for Future Building Envelopes, International Conference on Building Envelope Systems and Technologies ICBEST, p 634-646

Dabija, A-M (2010) Rehabilitation of Mass Dwellings in Romania. A Critical Approach International World Energy System Conference; Universitatea Valahia, Târgovişte, publicată în volumul 3 al The Scientific Bulletin of Electrical Engineering Faculty

Dabija, A-M (2016) Coridorul solar al clădirii istorice a Universităţii de Arhitectură și Urbanism "Ion Mincu” - conferința CNCISC, organizată în parteneriat cu Academia de Stiințe Tehnice a României,

\section{Referinţe web/Web references}

http://www.footprintnetwork.org/our-work/ecological-footprint/

http://green.gov.md/print.php?1=en\&idc=30\&id=43

http://www.mediafax.ro/social/reportaj-38-de-ani-de-la-cutremurul-din-vrancea-in-77-nustia-nici-presedintele-acum-se-afla-imediat-foto- 13925840 